\title{
HOW GLOBAL IS YOUR BUSINESS SCHOOL? - THE 3 PS OF INTERNATIONALIZATION: PROGRAMS, PARTICIPANTS AND PURPOSE
}

\begin{abstract}
In this paper, we introduce a three-factor framework that can be used to evaluate the internationality of universities offering international business by focusing on their programs, participants, and purpose. We illustrate how a prospective American student, and her parents could use the framework by applying it to four U.S. based business schools with international business programs, two large public schools and two smaller private schools. We argue that the framework may also be used by administrators and accreditors evaluating the institution from within. We gather our information from publicly available sources. We find that programs vary widely, both in depth and breath. Prospective students could use our framework to select the school that best fits their goals and skills. One ancillary finding is that the lack of transparency by most institutions makes gathering relevant information difficult.
\end{abstract}

Keywords: Business education, Internationalization, Comparing institutions

\section{Madan Annavarjula}

Bryant University

Jack Trifts

Bryant University

Andres Ramirez

Bryant University

Correspondence: Andres Ramirez

Bryant University,

1150 Douglas Pike, Smithfield RI 02917, U.S.A.

E-mail: aramirez@bryant.edu 


\section{INTRODUCTION}

A review of almost any business school's promotional materials and web site will quickly find references to that school's commitment to educating its students for a world that extends beyond the country's borders. It is rare to find any business school, regardless of size or stature to not make promises about how they prepare students to "work in the global economy," develop "an appreciation for global perspectives," or provide learning in "a global business context." Yet the degree of international focus of business schools varies greatly. Some schools have extensive international programs that involve all or most students, require second language training or proficiency, and send large numbers of students to study abroad. Others, despite their statements, are largely domestically oriented with their international focus being limited to a small number of international elective courses.

The purpose of this article is to provide a framework for measuring the degree of "internationalness" of a business school and to provide a basis for comparing programs. It is intended that this framework will be of benefit to both those inside business schools and to the prospective consumers of business school education. Faculty and administrators may use this framework to compare the approach to providing a globally focused education to competitors or aspirant schools. Prospective students, and their parents, may use this framework to systematically evaluate and compare programs. It is not the intent of this paper to assert that one model of business education is superior to others or even to assert that all good business education must be global in focus. While we believe that all students should have some understanding of business beyond their home country, many students have no interest in pursuing a career that will take them to live abroad or require them to develop proficiency in another language. Hopefully, our framework will help better match business schools with their prospective students.

This paper is organized as follows. First, we review the existing literature, looking at both prior research and writings on the internationalization of business schools and on the literature about multinationality in the corporate world. Next, we present a threefactor theoretical framework that can be used to measure and compare the degree of focus on international business in institutions based on the programs, participants, and purpose of each institution. We then discuss how this framework can be applied to provide meaningful comparisons in practice. Finally, we apply our framework to four 
schools with international business programs: two large public research institutions and two smaller private schools. The example in our paper is written from the point of view of an American student trying to choose the best American university to enroll in. We chose this approach mainly for our previous knowledge of the U.S. university system and the data required for the framework. A student from a different country would have to adopt the framework.

\section{LITERATURE REVIEW}

The relevant literature falls into two broad areas. First, much has been written about the internationalization of Business Schools. Some of this work is descriptive in nature while some other is normative. Second, there is a body of literature that has developed around the topic of the internationalization (sometimes referred to as multinationality) of businesses. This literature addresses the issue of how one might gauge how "international" a business really is. The framework we propose in the next section draws heavily on this work.

\section{Internationalization of business schools}

One of the most comprehensive early histories of the internationalization of business schools was written by Voris (1997), then President Emeritus of Thunderbird, The American Graduate School of International Management. Voris argues that while the history of international trade dates back as far as the Bible's book of Genesis, international business as a discipline of study is a product of the post-World War II era. He notes that his institution, Thunderbird, the first school in the United States to focus on international business, with emphases on modern languages, international studies in addition to business management, was founded in 1946. In comparison, he notes that most other business schools took a conservative approach to international business. For example, it was not until 1959 that the Academy of International Business (AIB) was established, and it was not until the 1980s when the then American Assembly of Collegiate Schools of Business (AACSB) began to enforce standards that required the inclusion of international business in member curriculums that the internationalization of American business schools began in earnest. The actual standards for accreditation changed in 1974 but Voris notes that it was an official interpretation of the standards, 
issued in 1980, that really began driving the change in curriculums. Reflecting its own refocus on international education, AACSB has since changed its name to AACSBInternational, the Association to Advance Collegiate Schools of Business. The steady but slow progress on the internationalization process is documented by AIB sponsored studies such as Kwok, Arpan, and Folks (1994) and Kwok and Arpan, (2002). Around this time schools begin to think inward, Crowther, Joris, Otten, and Nilson (2000) coin the term Internationalization at Home $(\mathrm{IaH})$ and ask institutions to expand their thinking to include any and all internationally related activity besides outbound students and staff mobility. Later Beelen and Jones (2015) place the attention on those students in the domestic learning environment by redefining $\mathrm{IaH}$ to intentionally include intercultural dimensions into formal and informal curriculums. De Wit and Jones (2018) suggest that traditional approaches to internationalization leave $99 \%$ of the world's student population behind, they suggest IaH efforts can help mitigate inequality in access. Similarly, Watkins and Smith (2018) argue that business schools should embed intercultural communication in order to serve all students.

This "global" aspect of the business school is cemented in Force (2011) AACSB International report on globalization, which places globalization as the center of higher education strategy and calls it the third wave of change. This internationalization process has also begun in business schools outside the USA. Progress has been documented in places such as Latin America Elahee and Norbis (2009), in the Arab world, Ahmed (2006), in Europe, Kwok and Arpan, (1994) and in the United Kingdom Bennett and Kane, (2011).

As Walton and Basciano (2006) note, the AACSB mandate requiring education in the international aspects of business did not prescribe any particular method. As a result, schools have adopted very different approaches to incorporating the international aspects of business education in the curriculum. Some schools require specific courses in international business while others encourage faculty to incorporate international topics throughout their previously domestically focused courses. Similarly, textbook authors have taken differing approaches to including international topics in their books. Some devote one or more chapters to international topics (typically the last ones) while other incorporate international topics throughout the book. In the end, the degree to which students are exposed to and learn about international business is at the discretion of their instructors, who choose what to emphasize and test in their courses. 
Several authors have developed helpful guides for schools seeking to become more international. For example, Hawawini, (2016) proposes specific elements such as "the internationalization of the curriculum, the creation of student and faculty exchange programs, and the participation in international academic and research partnerships." Another example is Scherer, Beaton, Ainina and Meyer (2000) who published A Field Guide to Internationalizing Business Education in which they provide a comprehensive list of areas for development. In his review of this book, Anwar (2002) notes the role of U.S. Department of Education in promoting international business in U.S. universities and colleges and highlights the book's usefulness in helping to build programs that align with those goals. While guides such as these can be invaluable, they are, by definition, broad in scope and thus their specific recommendations may not be relevant for the mission or resources of a specific school. Forray and Goodnight (2010) address this issue and note that institutions have tended to follow one of two approaches to internationalizing. The first is to adopt "best practices" observed at other institutions, particularly those who won awards or special recognition, and the second is to follow what they term "generic recommendations of experts" presumably including sources like Meyer's Field Guide but also including statements from CEOs of top firms, top exporters and other experts. They note that "while clearly useful as a kind of "shopping list" for those interested in internationalization and globalization, the "best practices/awards" approach or the "experts" approach provides inadequate guidance to a specific program with limited resources and particular program content" Forray and Goodnight (2010), p. 58. They argue that a key aspect of any school's internationalization efforts should be to assess the needs of the institution's stakeholders, including the needs of its students, the employers of its graduates, the needs of its local community, and constituents such as local and state governments. These market needs must be reconciled and aligned with the school's mission.

Building on the work of Wind, Duglas, and Perlmutter (1973), Moses, Moore, Pleasant, and Vest (2011) present a model for describing the degree of internationalness of a business school in four stages, ethnocentric business schools are focused on their domestic economy although they may have some international aspects infused in traditional courses. Polycentric schools are involved in internationalization but approach it on a country-by-country basis. Polycentric schools may develop partnerships and/or expertise with specific countries and languages. Regiocentric schools approach internationalization on a regional basis and focus on developing expertise and connections 
in particular parts of the world such as Latin America or Asia. Finally, geocentric schools are those few whose curriculum, programs and outreach is truly global in focus. It may be tempting to regard the E.P.R.G. model as a four-stage development plan for schools with every business school moving or at leasing desiring to move from ethnocentric to geocentric over time. However, as Forray and Goodnight (2010) point out, individual schools have unique missions and their stakeholders have varying needs. As a result, the ideal stage on the E.P.R.G. continuum is not the same for each institution. That is, while some schools may appropriately seek to be global in focus and thus strive to be truly geocentric, others may serve a much more local constituency and best serve their mission by being ethno or polycentric. As they note, one size does not fit all.

Trevino and Melton (2002) use the number of international course offerings at each school as a proxy for its degree of internationalness and seek to explain the factors that influence school's decision to focus on international business. They found that older schools tended to offer more international business (IB) courses as did schools with higher tuition rates. They also noted that higher numbers of international course offerings were associated with lower student/faculty ratios and smaller class sizes. Schools in urban areas and those in states bordering a foreign country were also likely to offer more international courses. They did note that there is a tendency for schools to substitute study abroad programs for on-campus course work as they found a negative relationship between schools with study abroad programs and their number of international course offerings.

\section{Internationalization of corporations}

While the globalization of business schools has been a slow process unfolding since the mid-twentieth century, corporations have been much quicker to see the benefits of international expansion. Modern structured multinational corporations such as the United East India Company have co-existed with domestic firms since the seventeenth century. Academics have offered several hypotheses to explain the internationalization phenomena, some of the best known are described below.

In some of the earliest work on the topic, Hymer (1976) building on Coase (1937) developed an internalization model where companies would invest abroad to control and "internalize" the market for key knowhow resources that would otherwise become public goods. Under this model, business schools should go abroad to protect their intellectual property. Another explanation is offered by Williamson (1985) who advanced that 
internationalization became the result of firms optimizing the costs of coordinating or information processing costs with a number of partners. We observe that as information processing becomes cheaper, transaction costs become less and less relevant. This hypothesis would suggest that business schools would expand with their own facilities in markets where institutions such as legal rights, law enforcement were an issue and more likely to partner or license in markets with good institutions. Vernon (1966) proposed an internationalization model based on the life cycle of products in which as product matures in domestic markets, firms find it advantageous to invest abroad in less developed markets. Under this model, old world universities would expand abroad where the market for education is less developed.

In the mid-1970s the Uppsala model of gradual internationalization was proposed by Johanson and Wiedersheim-Paul (1975) and Johanson and Vahlne (1977). They report empirical evidence that firms tend to begin their internationalization process with ad hoc exporting to agents, then to their own sales organizations, to finally manufacturing in foreign markets. The Uppsala model would suggest that universities would start with low effort engagements such as study abroad, student and faculty exchanges before opening full campuses abroad. Finally, we mention the "born global" concept presented by Knight and Cavusgil (1996) who define firms that "from or near their founding seek superior international business performance." This hypothesis would suggest that some universities or schools would be designed and launch to serve a global community from the very beginning. Despite technology and resources available, we have not seen universities take this path 1 .

Finally, academics have also attempted to measure the degree of internationalness in corporations. A most cited article is Sullivan, (1994) who critiques how most articles have relied in a single metric; foreign sales as a percentage of total sales, as a proxy for degree of internationality. Sullivan posits that no single factor can represent a complex construct and he presents a five-factor 2 model that arises from three attributes 3 . Later, Annavarjula and Beldona (2000) develop a conceptual model to measure the degree of multinationality of companies. Their model defines how multinational an organization is in terms of three criteria: operations, ownership, and orientation.

1 An application of this framework to business schools can be found in Guillotin and Mangematin (2015). 2 The variables are: FSTS; Foreign sales as percentage of total sales. FATA, Foreign assets as percentage of total assets. OSTS, Overseas subsidiaries as a percentage of total subsidiaries. TMIE, Top managers' international experience. PDIO, Psychic dispersion of international operations.

3 The attributes are performance, structural, and attitudinal. 


\section{CONCEPTUAL FRAMEWORK: THE 3 PS OF BUSINESS SCHOOL INTERNATIONALIZATION}

Our framework borrows from the work of Annavarjula and Beldona (2000) but reconceptualizes their three-factor model for higher education. Using the needs of higher education, we propose a similar three-factor framework of programs, participants, and purpose. Each of these factors has many facets that should be considered when measuring how "international" a school has become.

\section{The first P: programs}

The breadth and depth of a school's international programs is at the heart of defining how international it is. However, program offerings are complex and multi-faceted, and the richness of students' experiences varies across offerings. For example, many institutions offer courses in international business, some in sufficient number to allow students to minor or major in the field. As a very simple measure, one might follow Trevino and Melton (2002) to lead and measure the degree of emphasis on international business by counting the number of IB courses offered by a particular institution. While this simple approach does provide useful comparisons between institutions, the richness of students' international experience is not captured by simple counting. A more detailed assessment of the internationalness of a school's programs might include:

Does the school offer a dedicated International Business Program with a separate major and/or degree?

Is language training part of the program and is that training required or optional? As (Johnson, 2017) shows, the expected level of language proficiency in IB programs varies widely. If language is required, are students required to develop a level of proficiency or only to complete a specific number of credits or courses?

Does the school facilitate and/or promote its faculty to pursue teaching and research abroad? Are foreign faculty invited to teach or do research at the school? Does the school have a faculty exchange agreement with any university? Some schools have created faculty exchange programs where foreign professors come for a semester or a year as domestic professors go abroad. These programs provide excellent intercultural 
experiences for both faculty and students. Some schools have visiting professors that fulfill a similar purpose.

Does the school offer study abroad opportunities and, if so, does the IB program require participation? If study abroad is not a mandatory part of the program, what proportion of students participates? Additionally, does the school have a dedicated study abroad office with staff to help students? In how many locations around the world do students regularly study?

Does the school offer opportunities for students of other countries to visit for a semester? How many visiting students do they have? Does the school provide ways to incorporate them to other students? Exchange programs do not have to be one way. For example, some universities in less developed countries make great efforts to attract shortterm visiting exchange students from abroad. These schools are likely providing a great international exposure to their domestic students who may not be able to go abroad themselves.

Does the school offer shorter duration international study trips? As noted by Yobaccio, Mohan, and Trifts (2012) these shorter trips help develop self-reliance in students, many of whom may not have previously been outside their home country. These trips, while short in duration, may serve as "ice-breakers" and result in students undertaking other international opportunities such as study abroad.

Does the school offer international internships? What proportion of students participate? How are the internships generated, by the school or by students?

Does the school offer collaborative programs with other institutions outside the U.S.? What is the nature of the collaboration? For example, some schools develop exchange programs with other institutions whereby an equal or near equal numbers of students from each school may attend a semester or more at the partner school. In these cases, there may be little coordination of programs beyond the exchange agreement and students who participate may have limited support in terms of curriculum coordination or student services. In other instances, partner institutions may have developed coordinated curriculums, with a range of courses at each institution pre-approved for credit at the partner school and have in place staffs to support students while away from their home universities. Dual degrees $(2+2$ or $3+1)$ would be an example of utmost collaboration and trust amongst institutions.

At the highest level of international commitment, some institutions have developed campuses in other parts of the world. In these cases, domestic students can live and study 
in another country, while enjoying the full support of their school. Faculty in these programs may be permanently assigned to each campus or may rotate from the home campus for time periods or to teach specific courses.

\section{The second P: participants}

A key element of international education is the development of an awareness of and comfort with other cultures. While traditional course work can highlight cultural differences, there is no substitute for practical experience interacting with members of another culture. One of the important results of study abroad programs, international internships and exchange programs is the cultural learning that occurs because of living in another country and interacting with the local population daily over an extended period. However, the development of cultural skills does not only occur when students leave their home campus. It can also result from the day-to-day interactions with faculty and students from other parts of the world. In this sense, not only the programs but the participants in those programs affect how international a program is and how successful it may be in providing a complete international education. It is also important to note that institutions vary widely in their level of international diversity. As Yobaccio et al. (2012) noted, "Even those students who take international business courses in university often do so with an American-centric perspective: American students in an American classroom with an American professor, studying a text written in English by another American." In these cases, even students who receive a top-quality classroom experience may lack any real experience with culture differences.

It is therefore important to look at the participants in international education. A more detailed assessment of the internationalness of a school's participants might include:

Who are the faculty and what are their backgrounds? This is not to suggest that U.S. born faculty are somehow less effective as international educators but rather that the richness of students' educational experience may be enhanced by working with faculty from around the world, including but not exclusively from the U.S. Even simple things like becoming accustomed to the accents of speakers from other countries may make students more comfortable in their later careers. Specifically, one might measure the proportion of faculty from outside the U.S. and the number of nationalities represented on the faculty. Alternatively, U.S. educated faculty could have a lot of relevant international experience, by having lived, taught, or worked abroad or via research. 
Who are the students and what are their backgrounds? Of at least equal importance is the level of international diversity in the student population. In the absence of real personal knowledge, students may be susceptible to stereotypes about other people and their cultures. The day-to-day interactions between students, both in class and out-of-class, can provide powerful learning opportunities and help limit students' reliance on stereotypes. Team exercises that bring students of different backgrounds together can enhance cultural learning. Specifically, what proportion of students come from outside the U.S. and from how many countries matter.

Who are the alumni of the program? What kind of careers have they pursued? Some alumni may reside in the U.S. but work in international business as member of the supply chain of a domestic company. Others may be working and living abroad, perhaps communicating in foreign language.

Measuring the international diversity of a school requires more than simply counting the proportion of international students. How (and even if) students interact makes a big difference. For example, some institutions focus on recruiting students from one country or region of the world and end up with classes that may seem very international in terms of the proportion of non-U.S. students but are really made up of two groups of students who have limited interactions. Some study abroad programs have similarly been accused of being "island programs" that recruit most of their students from the U.S. and then offer American style courses sometimes even taught by American instructors. In these cases, students have much less opportunities to get to know local students and end up with many fewer opportunities for developing intercultural skills. Local universities in attractive destinations for receiving U.S. students typically create separate administrative units to attract, recruit and retain them. For them, it has become a source of income. We are not claiming that a full immersion is the only way to achieve the desired outcomes of multicultural awareness. In fact, Norris and Dwyer (2005) with data from a longitudinal study of alumni of the Institute for the International Education of Students (IES), provide evidence to the contrary. They conclude there is no difference between the groups. More recently, DeLoach, Kurt, and Olitsky (2019) reach a similar conclusion, the duration of the study abroad matters more than the intensity of it. Measuring the degree of interactions from outside the institution is difficult but the impact of these interactions should be considered by those building international programs. 


\section{The third P: purpose}

Institutions of higher education serve several purposes and, as a result, may focus their efforts quite differently from their peers. Some institutions see their role in global terms and seek to develop programs, recruit faculty and students and develop a reputation that goes well beyond domestic borders. Others are much more regional or local in their focus. There are many high-quality institutions with missions to support the local community through education and outreach programs. In most cases, these schools are likely to be less focused on international issues than on domestic and local ones. Similarly, these schools are more likely to focus on the education of local students and may have significant numbers of part-time and non-traditional students. Trevino and Melton (2002) find that business schools located in urban areas and those in states bordering another country were likely to have emphasis on international business.

Measuring the degree of internationalness of a school's purpose is challenging. While mission statements should provide the reader with the purpose of the institution but as noted in the introduction, almost everyone claims some degree of international focus. This is particularly true of business schools so one must look beyond simple statements and look for more concrete indications of purpose.

Accreditations may provide one such indication. Today, several business schools of merit (at least in the U.S.) have earned accreditation from AACSB International. As previously discussed, the current AACSB standards require international business to be part of the curriculum but provide wide latitude to institutions in meeting that standard. Many schools in Europe and more recently some in the U.S. have earned European Quality Improvement System (EQUIS) accreditation from the European Foundation for Management Development (EFMD). Like with AACSB, EQUIS accreditation is a substantial undertaking and likely to only be pursued by schools with a strong commitment to international education.

Another organization, albeit less formal than AACSB or EFMD, that has emerged in the U.S. as a significant advocate for international education is the Consortium for Undergraduate International Business Education (CUIBE). CUIBE originally began as a small group of the best undergraduate IB programs in the U.S. and was until the late 2000s, closed to additional membership. Recently however, CUIBE has begun inviting other schools to join, including ones abroad. While not an official accreditor of programs, 
as members join, they undergo a substantial program review including an on-campus site visit and concludes with a report with recommendations. CUIBE seeks to enhance members' programs via information sharing, consultation, and coordination. In fact, CUIBE requires schools to actively participate in meetings hosted at different member schools. In these meetings, guest faculty and staff have a chance to learn about the best practices from professors, students, alumni, and business executives in the host institution. CUIBE provides its members a benchmark to compare and improve their own program. Membership in CUIBE requires time and resources and is an indication of a school's commitment to international education at the undergraduate level.

We believe that the degree of internationalness of a particular school can be conceptualized by combining these three factors of programs, participants, and purpose. At one extreme, the most international program would be offered by an institution that focuses globally, has an extensive array of international programs around the world and brings together both students and faculty from around the world. At the other extreme would be programs offered by local institutions focused on local students and outreach. While that program might include few offerings in international business, it would not offer either the depth or breath of international programs of its more international peers.

\section{APPLYING THE FRAMEWORK}

To illustrate how one might use our constructs to measure the internationalness of an institution, we applied our framework to four institutions. We chose 2 large public universities and 2 small private ones. The first institution is a large public school with an IB program that has consistently ranked at or near the top by major publications including US News and World Report, the Financial Times, and the Wall Street Journal. We label this institution LaPu1. The second institution is another large public university whose IB program has been ranked in the top 25 by US News and World Report since 2005. We label it LaPu2. The third school is a small private university with a long-established program that has been ranked top 10 by college factual. We label it SmPr1. Finally, we include another small private university with a relatively young IB program, that is also ranked in the top 10 of college factual. We label it $\mathrm{SmPr} 2$. The identity of each school is available upon request. 
It is worth noting that the information is not always easy to find. We had to make compromises as we built the proxies that we believe capture the main constructs. One important contribution of this paper is to show where/how to find it. We gathered all the information from public sources, mostly within each school's website, but some from government sites, while other from commercial sites such as LinkedIn or college factual. Much of the program information required detailed scrutiny of the institution's catalog. Information on faculty required detailed examination of their individual web pages and sometime their CVs. Even then, not all faculty listings were complete.

Table One shows the metrics related to each school's first P: programs. All the information for this table came from each of the universities' sites. By almost any measure, one must conclude that each of these schools offers a very detailed and concentrated international experience from a program perspective, albeit with some significant differences. For example, LaPu1 not only offers a separate IB program but does so in two tracks, one with cohorts of students from specific regions of the world. All schools offer and require some sort of language training; however, $\mathrm{LaPu} 1, \mathrm{LaPu} 2$ and $\mathrm{SmPr} 2$ require courses in one language while SmPr1 allows for a combination or global studies courses with some upper-level language classes. All schools offer functional concentrations beyond IB, with LaPu1 requiring IB students to be dual majors and the other schools offering specific functional concentrations within the IB programs.

International internships are another area where schools' offerings and requirements vary widely. $\mathrm{SmPr} 1$ and $\mathrm{SmPr} 2$ require one, however SmPr1 allows for the internship to take place in the U.S. provided there is a reflection piece. For LaPu1 and LaPu2 students, international internships are available but not required.

Each school offers and requires some sort of study abroad opportunity but while $\mathrm{SmPr} 2$ and $\mathrm{LaPu} 2$ require one semester abroad, $\mathrm{LaPu} 1$ students are required to do one semester but may do a full year abroad. SmPr1 offer its students the possibility of satisfying this study abroad requirement by having relevant prior experience living and/or working abroad or by taking a shorter faculty led program. Closely related to study abroad, SmPr1, SmPr2 and LaPu2 offer a wide range of short-term study trips each year while LaPu1 has done so in the past but does not regularly offer them.

All schools make sure to showcase their collaborative programs with other universities. Not surprisingly, the larger schools in the sample, LaPu1, and LaPu2, have networks much larger than those of smaller SmPr1 and SmPr2. A caveat is that institutions do not disclose how active these agreements are. It could be that some 
alliances exist in paper only. We also note that LaPu1 has more complex agreements such as international cohorts and $2+2$ programs. Interestingly, despite its size, $\mathrm{SmPr} 1$ has a dual degree program with a German university.

Finally, SmPr2 operates a small campus in China, LaPu2 operates centers in China and Switzerland, while LaPu1 and SmPr1 have decided to not pursue international campuses.

Table Two shows the metrics related to the second P: participants in these IB programs. The first participant we look at is faculty. As we noted earlier, we believe that exposing students with a range of international backgrounds contributes positively to their development of cultural awareness. But how does one determine which faculty have international backgrounds? Almost no institutions report the original citizenship of their faculty. As a proxy, we recorded whether faculty had received degrees from institutions outside the U.S. We selected this proxy initially under the assumption that most people receive their undergraduate degrees in their home country and then come to the U.S. or elsewhere for graduate education. In most cases, we did note faculty with initial degrees outside the U.S. and graduate degrees from within the U.S. In two cases, we noted faculty with U.S. undergraduate degrees and non-US doctorates.

Table 1: First P: programs

\begin{tabular}{|c|c|c|c|c|}
\hline & Large-Public \#1 & Large-Public \#2 & Small-Private \#1 & $\begin{array}{c}\text { Small-Private } \\
\# 2\end{array}$ \\
\hline $\begin{array}{l}\text { Separate IB } \\
\text { Program? }\end{array}$ & $\begin{array}{l}\text { Yes. International } \\
\text { Business Bachelor of } \\
\text { Science in Business } \\
\text { Administration. There } \\
\text { are two tracks offered, } \\
\text { Classic, where } \\
\text { students take courses } \\
\text { at home plus a } \\
\text { semester abroad and } \\
\text { Cohort, where } \\
\text { students are placed in } \\
\text { a 2-year cohort with } \\
\text { students from Latin } \\
\text { America, Asia, Middle } \\
\text { East, or Europe. 15 } \\
\text { hours of IB courses } \\
\text { required plus a second } \\
\text { major in business }\end{array}$ & $\begin{array}{l}\text { No, offered as a major. } \\
\text { However, the website } \\
\text { refers it as program. } \\
\text { Students must choose a } \\
\text { concentration from a) } \\
\text { Global trade, b) } \\
\text { Sustainable } \\
\text { development, } \\
\text { Entrepreneurship, d) } \\
\text { Finance, e) Hospitality } \\
\text { Business Management, } \\
\text { f) Management, g) } \\
\text { Management } \\
\text { information systems, h) } \\
\text { Marketing }\end{array}$ & $\begin{array}{l}\text { Yes, at least in website. } \\
\text { Offered also as a minor. } \\
\text { Concentrations are } \\
\text { offered in Finance, } \\
\text { Marketing, and Family } \\
\text { Businesses and } \\
\text { Entrepreneurship. }\end{array}$ & 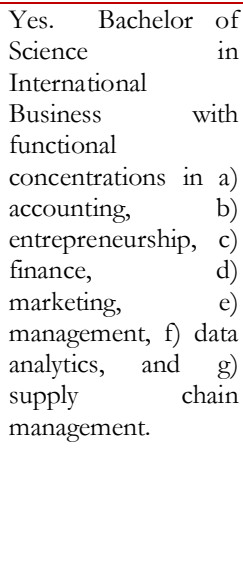 \\
\hline
\end{tabular}




\begin{tabular}{|c|c|c|c|c|}
\hline $\begin{array}{l}\text { Language } \\
\text { Training? }\end{array}$ & $\begin{array}{l}\text { Yes, Required. At } \\
\text { least four } 300 \text { level } \\
\text { courses must be } \\
\text { taken. }\end{array}$ & $\begin{array}{l}\text { Yes, One year at } \\
\text { college level. Could test } \\
\text { out via proficiency. } \\
\text { Arabic, } \\
\text { French, Chinese, } \\
\text { Italian, German } \\
\text { Korean, Japanese, } \\
\text { Spanish. }\end{array}$ & $\begin{array}{l}\text { Yes, language other than } \\
\text { English required. It } \\
\text { could be satisfied by } \\
\text { demonstrating } \\
\text { proficiency, getting a } \\
\text { major in German, } \\
\text { Russian, French, or } \\
\text { Spanish. Or a } \\
\text { combination of global } \\
\text { studies courses with } \\
\text { some upper-level } \\
\text { language classes. }\end{array}$ & 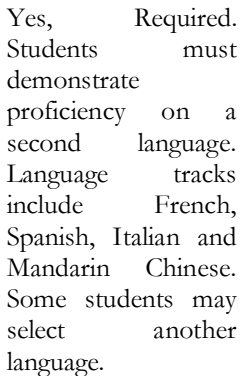 \\
\hline $\begin{array}{l}\text { Study } \\
\text { Abroad? }\end{array}$ & $\begin{array}{l}\text { Yes, } \\
\text { Minimum } r \text { onuired. } \\
\text { semester with an } \\
\text { option for one year. }\end{array}$ & $\begin{array}{l}\text { Yes, Required. At least } \\
11 \text { weeks in length and } \\
12 \text { transferable credits }\end{array}$ & $\begin{array}{l}\text { IB majors are required } \\
\text { to have a direct } \\
\text { international experience. } \\
\text { This requirement may } \\
\text { be satisfied by (a) } \\
\text { participating in a } \\
\text { semester abroad } \\
\text { program, } \\
\text { participating in an } \\
\text { approved study abroad } \\
\text { course, (c) by experience } \\
\text { as an international } \\
\text { student studying in the } \\
\text { U.S., or (d) by extensive } \\
\text { experience living or } \\
\text { working abroad at age } \\
16 \text { or older }\end{array}$ & $\begin{array}{l}\text { Yes, Required. All } \\
\text { students are required } \\
\text { to spend one } \\
\text { semester abroad. }\end{array}$ \\
\hline $\begin{array}{l}\text { Short- } \\
\text { Duration } \\
\text { Study Trips? }\end{array}$ & $\begin{array}{l}\text { No. Only Winter } \\
\text { programs offered. } \\
\text { International travel } \\
\text { study was offered in } \\
2017 \text {. }\end{array}$ & $\begin{array}{l}\text { Faculty led programs } \\
\text { open to all students. } \\
\text { Spring Break and } \\
\text { Summer. Cultural } \\
\text { aspects plus a business } \\
\text { class. Belize, China, } \\
\text { Croatia, Egypt, } \\
\text { Germany, Greece, } \\
\text { Ireland, Italy, Romania } \\
\text { and Croatia, Spain, } \\
\text { Thailand. }\end{array}$ & $\begin{array}{l}\text { Field Studies: brief } \\
\text { faculty-led trips. } \\
\text { Department of Art and } \\
\text { Art History Field } \\
\text { Studies have featured } \\
\text { opportunities to explore } \\
\text { ancient Pompeii, study } \\
\text { Galapagos ecotourism, } \\
\text { and make art in Scotland } \\
\text { during the Edinburgh } \\
\text { Art and Fringe Festivals. } \\
\text { Faculty have also led art } \\
\text { and art-historical trips to } \\
\text { New York, Paris, and } \\
\text { Rome. Costa Rica } \\
\text { available for freshmen }\end{array}$ & $\begin{array}{l}\text { Yes. "Sophomore } \\
\text { International } \\
\text { Experience" trips are } \\
\text { offered to a range of } \\
\text { destinations in } \\
\text { Europe, South } \\
\text { America, and Asia }\end{array}$ \\
\hline $\begin{array}{l}\text { International } \\
\text { Internships? }\end{array}$ & $\begin{array}{l}\text { Yes, but not required. } \\
\text { Offered via third } \\
\text { party vendors. }\end{array}$ & Yes, but not required. & $\begin{array}{l}\text { Yes, required. However, } \\
\text { it could be done in the } \\
\text { U.S. with IB reflection. }\end{array}$ & $\begin{array}{l}\text { Yes, Required. IB } \\
\text { students are required } \\
\text { to complete an } \\
\text { internship during } \\
\text { their study abroad. }\end{array}$ \\
\hline
\end{tabular}




\begin{tabular}{|c|c|c|c|c|}
\hline $\begin{array}{l}\text { International } \\
\text { Collaborative } \\
\text { Programs? }\end{array}$ & 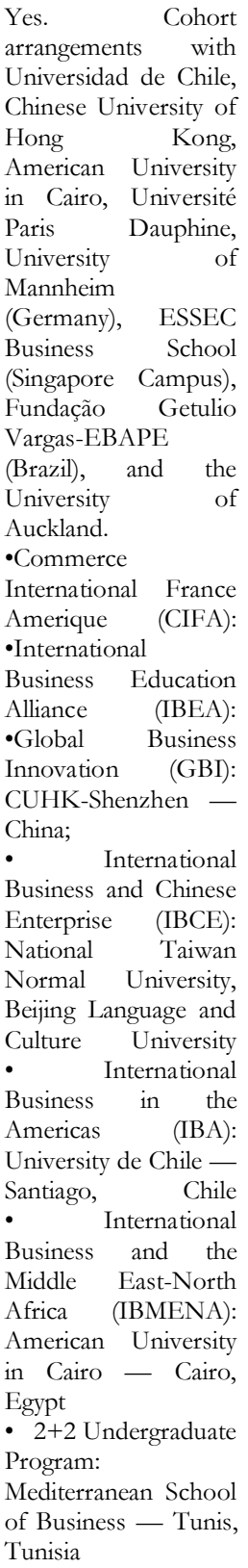 & 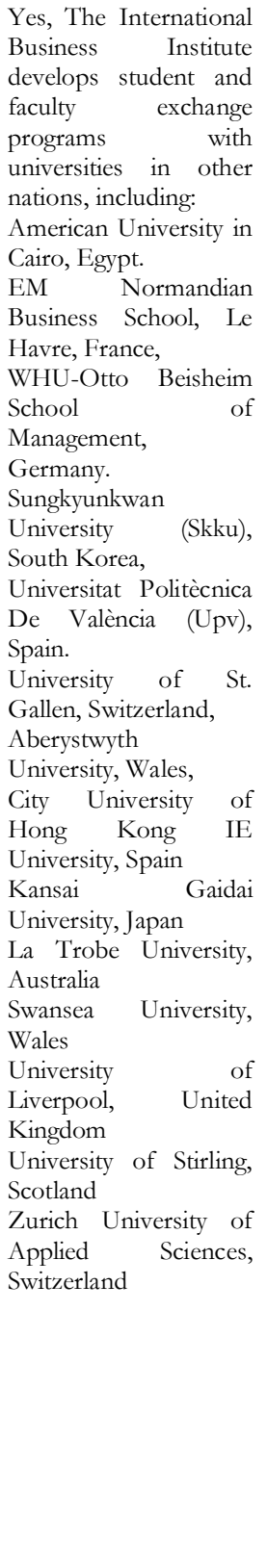 & $\begin{array}{l}\text { Yes, direct agreements } \\
\text { with, } \\
\text { Hong Kong Baptist } \\
\text { University, China. } \\
\text { Kansai Gadai University } \\
\text { Japan. } \\
\text { Al Akhawayn University } \\
\text { Morocco. } \\
\text { University of Oviedo, } \\
\text { Spain. } \\
\text { In addition, the } \\
\text { institution offers a dual } \\
\text { degree with Reutlingen } \\
\text { University in Germany }\end{array}$ & $\begin{array}{l}\text { Yes. Direct exchange } \\
\text { agreements with } \\
\text { University of the } \\
\text { Sunshine Coast, } \\
\text { Queensland, } \\
\text { Australia } \\
\text { University } \\
\text { Birmingham, } \\
\text { Birmingham, } \\
\text { England } \\
\text { University of } \\
\text { Hertfordshire, } \\
\text { Hatfield, England } \\
\text { Universität } \\
\text { Konstanz, Konstanz, } \\
\text { Germany (Available } \\
\text { for Spring semesters) } \\
\text { Dublin City } \\
\text { University, Dublin, } \\
\text { Ireland } \\
\text { Universitá Cattolica } \\
\text { del Sacro Cuore, } \\
\text { Milan, Italy } \\
\text { University of Trento, } \\
\text { Trento, Italy (Italian } \\
\text { speakers only!) } \\
\text { Universidad } \\
\text { Francisco de Vitoria, } \\
\text { Madrid, Spain }\end{array}$ \\
\hline $\begin{array}{l}\text { International } \\
\text { Campus? }\end{array}$ & No. & $\begin{array}{l}\text { International centers in } \\
\text { China and Switzerland }\end{array}$ & No & $\begin{array}{l}\text { Yes. University } \\
\text { operates a campus in } \\
\text { China. }\end{array}$ \\
\hline
\end{tabular}

Source: universities' websites 
We also acknowledge that foreign faculty with foreign degrees may not be interested at all on international topics. At the same time, faculty with U.S. degrees could have lived, worked, taught, researched and otherwise passionate about everything international. For that reason, we investigated each faculty's profile to get a sense of this. We found that some schools like LaPu1 do a great job highlighting this experience on their faculty, while other schools, fail to mention the rich experience some faculty have. The last item we look in faculty is a proxy for the diversity of backgrounds. We do so by counting from how many countries do they have degrees from.

The second participant is the student body. We found that that detailed information about specific programs can be difficult to find. For the four institutions, detailed student counts and international background information for all business undergraduates was not available from public sources so we had to use the information a prospective student or parent could find freely available. The National Center for Education Statistics in its website college navigator publishes a wealth of information about every institution. Amongst the data points are the percentage of students who are nonresident aliens in campus as well as the percentage of students whose domicile is a foreign country. We believe these metrics provide a good indicator of the internationalness of the campus experience. As one would expect, the large schools in our sample have a lower proportion (about $4 \%$ ) of nonresident students than the smaller institutions (about $8 \%$ ). This is likely the result of the recruiting efforts of private institutions. It is also interesting to note that a significant portion of those nonresident aliens have domiciles in the U.S. We do not have an explanation for this, but we conjecture that their families may have immigrated recently or being in U.S. for work. No matter which metric, a prospective student from the U.S. is more likely to encounter foreign classmates in a smaller institution.

U.S. students enrolled in international business are a self-selected group with a marked interest in global aspects of business. A finer picture emerges when we look at where those foreign students are within each institution. We look at the ratio of international students that graduated in 2019 from each IB program. Results vary widely, on one extreme $51 \%$ and $29 \%$ of the IB graduating classes at LaPu2 and $\mathrm{SmPr} 1$ respectively were composed of nonresident alien students while the figures are $10 \%$ for SmPr2 and a mere $2 \%$ for LaPu1. From this we can conclude that international students gravitate heavily towards IB in all schools but LaPu1.

Next, a prospective student could be interested in how big each school's IB program is. In other words, is the school focused on IB? To answer this question, we look 
at the number of IB degrees awarded in 2019 as a percentage of total business degrees awarded. Here we can see that SmPr1 and SmPr2 are the most focused with $29 \%$ and $11 \%$ respectively, while LaPu2 and LaPu1 lag with $4 \%$ and $2 \%$ respectively.

The third participant we analyze is the alumni. We acknowledge that an international business career can take many forms, such as immersion in a foreign country and language or working in a domestic firm that exports or imports. Prospective students may like to know how international past graduates are to assess how much expertise, coaching and advise they could get in their own careers. Our first instinct was to look at the alumni sites of each institution. Unfortunately, none of the schools provide much if any information about its alumni. We looked online at alumni groups abroad as a proxy for the resources a potential student could get. We found that LaPu1 is the only institution with alumni groups abroad (London and Germany). Next, we are interested in those alumni working in IB jobs abroad as well as those working in IB jobs in the U.S. We turned to LinkedIn and searched for people with key words "international business" as a proxy for work experience who attended each school. We filtered for residence in selected countries 4 and then compared against those with U.S. residence. We found that LaPu1 and LaPu2 have the largest number of alumni working abroad with 980 and 761 respectively and 15,000 and 13,000 working in the U.S. SmPr1 and SmPr2 follow with 253 and 208 alumni abroad and 5,200 and 6,400 alumni in the U.S. If we look at these figures as a ratio, we can see that LaPu1 seems to have the highest proportion of alumni working abroad. We are aware that these alumni proxies are noisy. For example, an alumnus may not have a LinkedIn page or chosen not to updated it with relevant international experience or current location. Our filter for "international business" may capture students who attended the program but who are not working on IB related fields. Despite its shortcomings we believe our proxy is not biased against any school.

The organization of the four schools is quite different. LaPu1 has a large dedicated IB department, while LaPu2 has an international business institute in which fellows from different departments teach. Some of SmPr1 professors have IB as their primary program while at $\mathrm{SmPr}$, IB faculty are drawn from functional areas across the business school.

\section{Table 2: Second P: participants}

\footnotetext{
${ }_{4}$ Countries included were Australia, Brazil, China, France, Germany, India, Italy, Japan, Mexico, South Korea, Spain, Thailand, United Kingdom, or Vietnam
} 


\begin{tabular}{|c|c|c|c|c|}
\hline & Large-Public \#1 & $\begin{array}{c}\text { Large-Public } \\
\# 2\end{array}$ & $\begin{array}{c}\text { Small-Private } \\
\# 1\end{array}$ & $\begin{array}{c}\text { Small-Private } \\
\# 2\end{array}$ \\
\hline $\begin{array}{l}\text { Total number of } \\
\text { IB faculty? } 1\end{array}$ & $\begin{array}{l}23 \text { Faculty listed in the } \\
\text { 9Department of } \\
\text { International Business. } \\
\text { Direct link to } \\
\text { individual profiles }\end{array}$ & $\begin{array}{l}17 \text { faculty listed } \\
\text { in the } \\
\text { international } \\
\text { business institute. } \\
\text { Also listed as IB } \\
\text { fellows. Direct } \\
\text { link to individual } \\
\text { profiles provided }\end{array}$ & $\begin{array}{l}17 \text { faculty listed } \\
\text { in business with } \\
5 \text { faculty } \\
\text { designated } \\
\text { primarily as IB. } \\
\text { Individual } \\
\text { profiles provided } \\
\text { in the same page }\end{array}$ & $\begin{array}{l}20 \text { faculty are } \\
\text { listed in the } \\
\text { catalog. There is } \\
\text { no link to their } \\
\text { profile there. } \\
\text { User must search } \\
\text { each name in the } \\
\text { general faculty } \\
\text { site. }\end{array}$ \\
\hline $\begin{array}{l}\text { IB faculty with } \\
\text { international } \\
\text { education }{ }^{1}\end{array}$ & $\begin{array}{l}9 \text { faculty have degrees } \\
\text { from outside the U.S. } \\
\text { plus } 1 \text { attended high } \\
\text { school outside the } \\
\text { USA. }\end{array}$ & $\begin{array}{l}4 \text { out of } 17 \\
\text { faculty have } \\
\text { degrees }\end{array}$ & $\begin{array}{l}5 \text { out of } 5 \text { faculty } \\
\text { have degrees } \\
\text { from foreign } \\
\text { universities. }\end{array}$ & $\begin{array}{l}10 \text { out } 20 \text { faculty } \\
\text { have degrees } \\
\text { from foreign } \\
\text { universities. }\end{array}$ \\
\hline $\begin{array}{l}\text { IB faculty with } \\
\text { international } \\
\text { experience } 1\end{array}$ & $\begin{array}{l}21 \text { faculty out of } 23 \\
\text { have relevant } \\
\text { experience abroad } \\
\text { such as research, } \\
\text { teaching, working, or } \\
\text { living abroad. }\end{array}$ & $\begin{array}{l}5 \text { faculty out of } \\
17 \text { have relevant } \\
\text { experience } \\
\text { abroad such as } \\
\text { research, } \\
\text { teaching, } \\
\text { working, or living } \\
\text { abroad. }\end{array}$ & $\begin{array}{l}5 \text { out of } 5 \text { faculty } \\
\text { have } \\
\text { international } \\
\text { experience either } \\
\text { living, working, } \\
\text { or teaching } \\
\text { abroad. }\end{array}$ & $\begin{array}{l}10 \text { faculty out of } \\
20 \text { have relevant } \\
\text { experience } \\
\text { abroad such as } \\
\text { research, } \\
\text { teaching, } \\
\text { working, or } \\
\text { living abroad. }\end{array}$ \\
\hline $\begin{array}{l}\text { Total number of } \\
\text { countries } \\
\text { represented by } \\
\text { IB faculty? } 1\end{array}$ & $\begin{array}{lr}\text { IB faculty have } \\
\text { degrees from } 6 \\
\text { countries including } \\
\text { the U.S. }\end{array}$ & $\begin{array}{l}\text { IB faculty have } \\
\text { degrees from } 5 \\
\text { countries } \\
\text { including the U.S. }\end{array}$ & $\begin{array}{l}\text { IB faculty have } \\
\text { degrees from } 6 \\
\text { countries } \\
\text { including the } \\
\text { U.S. }\end{array}$ & $\begin{array}{l}\text { IB faculty have } \\
\text { degrees from } 8 \\
\text { countries } \\
\text { including the } \\
\text { U.S. }\end{array}$ \\
\hline $\begin{array}{l}\text { Students who are } \\
\text { nonresident } \\
\text { aliens enrolled in } \\
\text { university as \% } \\
\text { of total student } \\
\text { population. } 2\end{array}$ & $4.00 \%$ & $4.00 \%$ & $9.00 \%$ & $8.00 \%$ \\
\hline $\begin{array}{l}\text { Students with } \\
\text { residence in } \\
\text { foreign countries } \\
\text { as \% of total } \\
\text { student } \\
\text { population. } 2\end{array}$ & $1.00 \%$ & $2.00 \%$ & $8.00 \%$ & $5.00 \%$ \\
\hline $\begin{array}{l}\text { IB nonresident } \\
\text { aliens graduates } \\
\text { as } \% \text { of total IB } \\
\text { graduation class } \\
\text { of } 2019.3\end{array}$ & $2.29 \%$ & $50.98 \%$ & $29.41 \%$ & $10.11 \%$ \\
\hline $\begin{array}{l}\text { International } \\
\text { business degrees } \\
\text { awarded in } 2019 \\
\text { as \% of total } \\
\text { degrees awarded } \\
\text { at school of } \\
\text { business level. } 4\end{array}$ & $2.18 \%$ & $4.48 \%$ & $24.51 \%$ & $7.81 \%$ \\
\hline
\end{tabular}




\begin{tabular}{|c|c|c|c|c|}
\hline $\begin{array}{l}\text { Alumni chapters } \\
\text { abroad. } 5\end{array}$ & London, Germany & None & None & None \\
\hline $\begin{array}{l}\text { Number of } \\
\text { alumni in IB jobs } \\
\text { in selected } \\
\text { countries } 6\end{array}$ & 980 & 761 & 253 & 208 \\
\hline $\begin{array}{l}\text { Number of } \\
\text { alumni in IB jobs } \\
\text { in U.S. }{ }^{7}\end{array}$ & 15,000 & 13,000 & 5200 & 6400 \\
\hline $\begin{array}{l}\text { Alumni abroad } \\
\text { as \% of alumni in } \\
\text { U.S. } 8\end{array}$ & $6.53 \%$ & $5.85 \%$ & $4.87 \%$ & $3.25 \%$ \\
\hline
\end{tabular}

1. Program website, faculty profile

2. College navigator

3. College factual and authors calculations.

4. College navigator and authors calculations

5. Alumni site of each school

6. LinkedIn search for "International Business" that reported attending each school, whose current location is Australia, Brazil, China, France, Germany, India, Italy, Japan, Mexico, South Korea, Spain, Thailand, United Kingdom, or Vietnam.

7. LinkedIn search for "International Business" that reported attending each school, whose current location is U.S.

8. Ratio of alumni abroad over alumni in U.S.

Table Three shows information about our third P: purpose. In general, we found information about schools' vision, mission, and purpose to be vague and unhelpful. LaPu1 does emphasize the school's focus on educating the state's residents and SmPr2's institution's website does note its integration of business and arts and sciences. SmPr1 mentions education for global citizenship and LaPu2 emphasizes the advancement of knowledge through creative research and scholarship. Each program refers to educating students with an international perspective using phrases referencing "global business," "global citizens," "global perspectives" and "a complex world." Like so many institutions we examined, their statements are overly general and do not speak to any real focus.

Accreditation offers one area where outside reviewers can ascribe the actual focus of these programs. Each of these schools is accredited by AACSB International and each is a member of CUIBE. Unlike their vague statements of mission and focus, these attributes suggest a substantial commitment to high-quality business education and to the schools' international business programs. 
Table 3. Third P: purpose

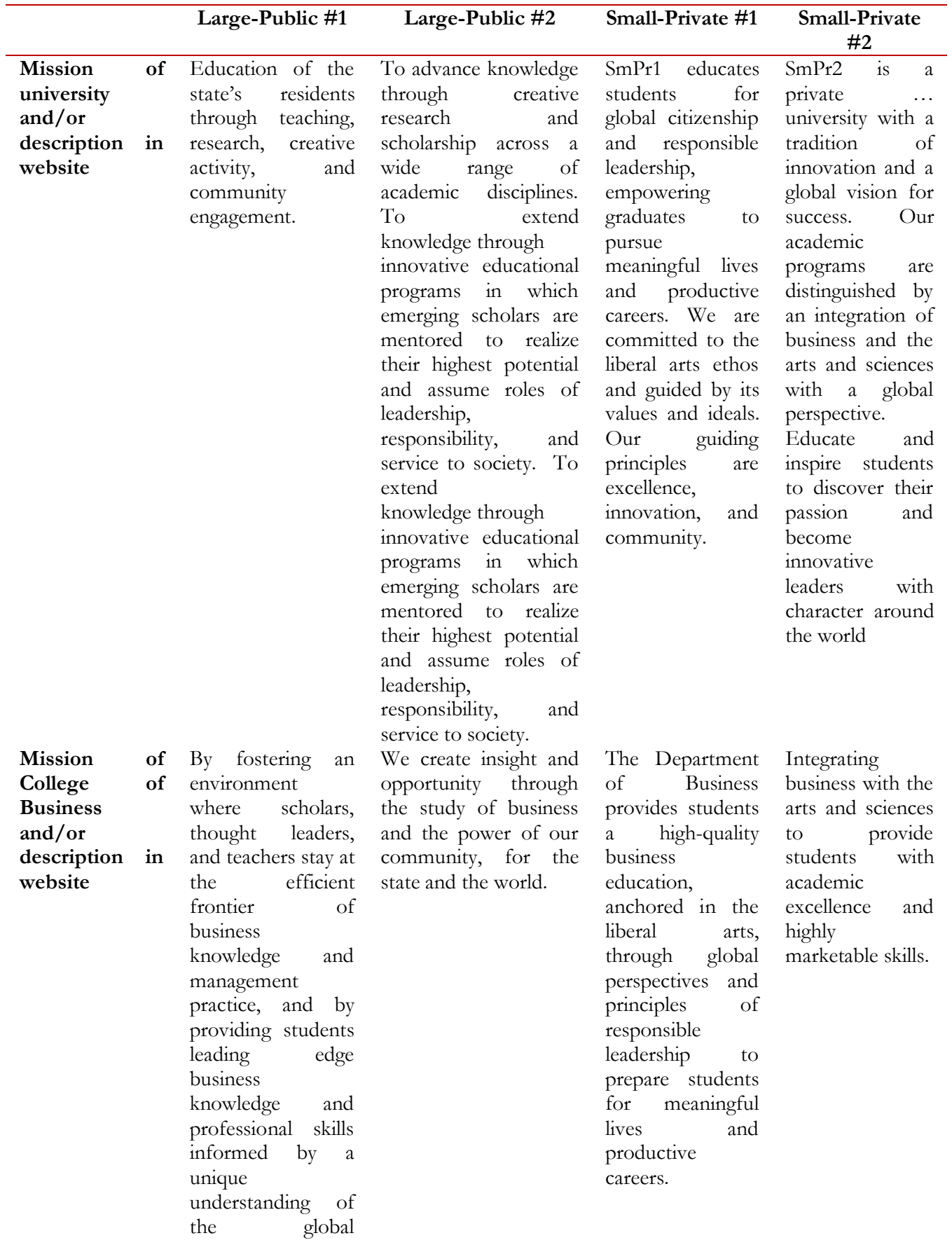




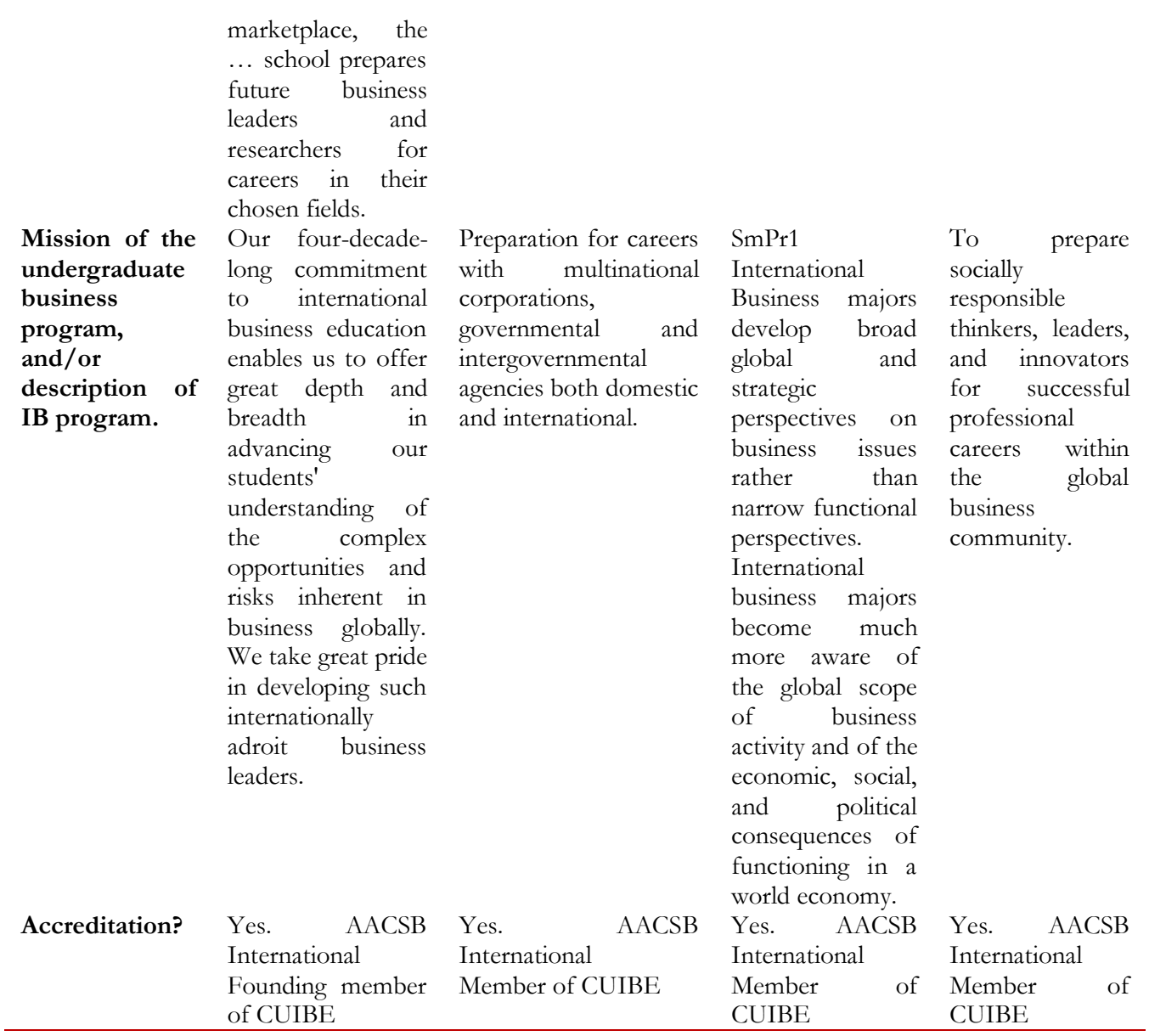

Source: universities' webs

\section{CONCLUSION}

In this paper, we propose a three-factor (3p's) framework to measuring the internationalness of a business school. We suggest that by focusing on a school's programs, participants, and purpose, one can develop a more tangible assessment of a school's commitment to and involvement in international business education.

We also highlight some of the difficulties faced by both institutions and prospective students in evaluating international business programs. Many, perhaps most, schools of business make at least veiled reference to preparing students to work in a global environment, although the international offerings can range from detailed immersive 
program with extensive study abroad requirements to curriculums that offer one or more international electives. Similarly, the degree of cross-cultural learning opportunities may range widely.

Our framework allows a prospective student to have in one place all information needed to make an informed decision. Those who desire to pursue an immersive experience could opt for a school that offers dual degrees or has its own campus abroad. Students who are less interested in language but more so on intercultural communication can choose a program with more flexibility on that regard. Students who want to have the most international experience while in the U.S. should look at how international its faculty and student body is. Yet those interested in a career in a particular region can look at the alumni network in that region. While our framework is flexible to meet the specific needs of our user who is interested in say a particular region or business function, the information is not readily available.

Online simulations lever technology to allow students to collaborate virtually. For example, the X-culture Taras, Bryła, Gupta, Jiménez, Minor, Muth, Ordenana, Rottig, Sarala, Zakaria, and Zdravkovic (2012) project has been used in IB programs since 2010 to enhance the cross-cultural learning experience of students by engaging them in projects with students from different countries. The advent of Covid and its worldwide restrictions brought several technologies such as distant lectures (synchronous and asynchronous) to the forefront of teaching and learning. We have witness how easy it is for foreign students to attend virtually from housing in or close to campus or from across the globe. Class appearances by guest speakers, or alumni residing in foreign countries, once an unaffordable luxury have become something more common. Hybrid methods of teaching and learning hold the promise to deliver a valuable international experience at a cost that many more students around the world could afford. We are unsure how schools, students and faculty will lever its potential, but we are certain it will play an important role and will have to be added to our framework.

An important lesson we have learned from this research is that institutions need to do a much better job of providing accurate and detailed information to the public. Even as experienced academics with deep knowledge of universities and business education, we found ourselves struggling to find basic information as simple as "how many students are in the IB program?" Prospective students and their families are likely to have even more difficulty and may end up making decisions on incomplete or inaccurate information. 
A note of caution should be given to potential users of our framework; there are nuances that are very hard to capture. For example, older, larger international business programs are much more likely to have alumni abroad. Our data does not distinguish if those alumni abroad are U.S. citizens pursuing a career abroad or foreign students who have returned home. Furthermore, we were not able to find information about what percentage of alumni working in the U.S. are international. Some schools may be the best fit for U.S. students interested in a career abroad, while other schools are better suited at training foreign students who want to work in the U.S.

Although data collection is time consuming and not likely to be automated, we foresee one institution, perhaps one from this sample, to collect and publish tables like those presented in this article.

\section{REFERENCES}

Ahmed, A. A. R. 2006. The internationalization of the business administration curricula in Arab universities. Journal of Teaching in International Business 18 (1): 89-107.

Annavarjula, M. and S. Beldona. 2000. Multinationality-performance relationship: A review and reconceptualization. The International Journal of Organizational Analysis 8 (1): 48-67

Anwar, S. T. 2002. Review of the Book A Field Guide to Internationalizing Business Education, by Scherer, R.F., Beaton, S.T., Ainina, M.F. and Meyer, J.F. Thunderbird International Business Review, 44(5), 681-684.

Beelen, J. and E. Jones. 2015. Redefining internationalization at home. In Springer, Cham, The European Higher Education Area (59-72).

Bennett, R. and S. Kane. 2011. Internationalization of UK university business schools: A survey of current practice. Journal of Studies in International Education 15 (4): 351-373.

Coase, R. H. 1937. The Nature of the Firm. Economica 4 (16): 386-405.

Crowther, P., M. Joris, M. Otten, B. Nilsson, H. Teekens, and B. Wächter. 2000. Internationalisation at home: A position paper. European Association for International Education.

de Wit, H. and E. Jones. 2018. Inclusive internationalization: Improving access and equity. International Higher Education 94: 16-18. 
DeLoach, S. B., M. R. Kurt, and N. H. Olitsky. 2019. Duration matters: separating the impact of depth and duration in study abroad programs. Journal of Studies in International Education. 25 (1): 100-118.

Elahee, M. and M. Norbis. 2009. Internationalizing business education in Latin America: Issues and challenges. Journal of Teaching in International Business 20 (4): 312-329.

Force, A. I. G. of M. E. T. 2011. Globalization of management education: changing international structures, adaptive strategies, and the impact on institutions: Report of the AACSB international globalization of management education task force. AACSB International.

Forray, J. M. and J. E. Goodnight. 2010. Think global, act local: A methodology for investigating international business curriculum priorities using stakeholder feedback. Organization Management Journal 7 (1): 56-64.

Guillotin, B. and V. Mangematin. 2015. Internationalization strategies of business schools: How flat is the world? Thunderbird International Business Review 57 (5): 343-357.

Hawawini, G. 2016. The internationalization of higher education and business schools: A critical review. Springer.

Hymer, S. H. 1976. International operations of national firms. MIT press.

Johanson, J. and J. E. Vahlne. 1977. The internationalization process of the firm-A model of knowledge development and increasing foreign market commitments. Journal of International Business Studies 8 (1): 23-32.

Johanson, J. and F. Wiedersheim-Paul 1975. The internationalization of the firm: Four Swedish cases. Journal of Management Studies 12 (3): 305-322.

Johnson, J. 2017. Foreign language training in U.S. undergraduate IB programs: Are we providing students what they need to be successful? Journal of Teaching in International Business 28 (1): 35-48.

Knight, G. A. and S. T. Cavusgil. 1996. The born global firm: A challenge to traditional internationalization theory. Advances in International Marketing 8 (1): 11-26.

Kwok, C. C., J. Arpan, and W. R. Folks. 1994. A global survey of international business education in the 1990s. Journal of International Business Studies 25 (3): 605-623.

Kwok, C. C. and J. S. Arpan. 1994. A comparison of international business education at US and European business schools in the 1990s. MIR: Management International Review: 357-379.

Kwok, C. C., and J. S. Arpan. 2002. Internationalizing the business school: A global survey in 2000. Journal of International Business Studies 33 (3): 571-581. 
Moses, C., K. Moore, J. Pleasant, and D. Vest. 2011. Adapting the EPRG paradigm to internationalizing business schools: A conceptual framework. International Journal of Business and Social Science 2 (23).

Norris, E. M. and M. M. Dwyer. 2005. Testing assumptions: The impact of two study abroad program models. Frontiers: The Interdisciplinary Journal of Study Abroad 11: $121-142$.

Scherer, RF, ST Beaton, MF Ainina, and JF Meyer. 2000. A Field Guide to Internationalizing Business Education. Austin, TX: Center for International Business Education and Research.

Sullivan, D. 1994. Measuring the degree of internationalization of a firm. Journal of International Business Studies 25 (2): 325-342.

Taras, V., P. Bryła, S. Gupta, A. Jiménez, M. Minor, T. Muth, X. Ordenana, D. Rottig, R. Sarala, N. Zakaria, and S. Zdravkovic. 2012. Changing the face of international business education: The X-Culture Project. Academy of International Business Insights 12 (4).

Trevino, L. J. and M. Melton. 2002. Institutional characteristics and preconditions for international business education-an empirical investigation. Journal of Education for Business 77 (4): 230-235.

Vernon, R. 1966. International investment and international trade in the product cycle*. The Quarterly Journal of Economics 80 (2): 190-207.

Voris, W. 1997. A retrospective of international business education in the United States over the past fifty years. The International Executive 39 (2): 271-282.

Walton, J. and P. Basciano. 2006. The internationalization of American business education: Are US business students less ethnocentric. The Business Review 5 (1): 282-286.

Watkins, H. and R. Smith. 2018. Thinking globally, working locally: Employability and internationalization at home. Journal of Studies in International Education 22 (3): 210224.

Williamson, O. E. 1985. The economic institutions of capitalism: firms, markets, relational contracting. The Free Press.

Wind, Y., S. P. Douglas, and H. V. Perlmutter. 1973. Guidelines for developing international marketing strategies. Journal of Marketing 37 (2): 14-23.

Yobaccio, E., R. Mohan, and J. Trifts. 2012. Developing international self-reliance in undergraduate students through study trips. Journal of the Academy of Business Education 13. 